\title{
Interactive Effects of Copper, Fluorene, and Fluoranthene on Enzymatic Biomarkers and Metallothionein Levels in Crucian Carp (Carassius auratus)
}

\author{
Guanghua Lu' ${ }^{1,2}$, Hao Wu ${ }^{2}$, Jiannan Ding ${ }^{3 *}$ \\ ${ }^{1}$ College of Hydraulic and Civil Engineering, XiZang Agricultural and Animal Husbandry College, \\ Linzhi, 860000, China \\ ${ }^{2}$ Key Laboratory of Integrated Regulation and Resources Development of Shallow Lakes of Ministry \\ of Education, College of the Environment, Hohai University, Nanjing 210098, China \\ ${ }^{3}$ School of the Environment and Civil Engineering, Jiangnan University, \\ Wuxi 214122, China
}

Received: 23 April 2017

Accepted: 11 July 2017

\begin{abstract}
To evaluate potential interactive effects of metals and polycyclic aromatic hydrocarbons (PAHs) on biomarker responses, groups of the freshwater fish crucian carp (Carassius auratus) were exposed to single and binary combinations of copper $(\mathrm{Cu})(0.01-0.16 \mathrm{mg} \mathrm{L}-1)$ with fluorene (Fl) or fluoranthene (Fluo) (2-10 $\left.\mathrm{mg} \mathrm{kg}^{-1}\right)$ for $96 \mathrm{~h}$. Dose-dependent increases in the activities of phases I and II metabolic enzymes [7-ethoxyresorufin O-deethylase (EROD) and glutathione-S-transferase (GST), respectively] were observed in fish liver exposed to Fl and Fluo, but these enzyme activities did not differ significantly from the controls when co-treated with higher concentrations of $\mathrm{Cu}$, suggesting an inhibiting interaction on the metabolic enzymes. Although $\mathrm{Cu}$ did not alter catalase (CAT) activity, CAT activity was decreased in fish liver exposed to the two PAHs alone or in combination with $\mathrm{Cu}$. Although metallothionein (MT) content in gills was significantly increased following exposure to $\mathrm{Cu}$ alone or in combination with $\mathrm{Fl}$ and Fluo, the induction folds of MT decreased under co-exposure. Co-exposures to these chemicals invoked complex biomarker responses in fish liver and gills. These results highlight the need for careful consideration of the interactive effects of multiple environmental stressors on fish.
\end{abstract}

Keywords: copper, fluorene, fluoranthene, carassius auratus, biomarkers

*e-mail: djn@jiangnan.edu.cn 


\section{Introduction}

Generally, inorganic and organic contaminants coexist in aquatic environments. These chemicals in mixtures may interact with aquatic organisms such as fish, and alter the toxicity of each chemical greatly. Metals and polycyclic aromatic hydrocarbons (PAHs) are, respectively, among the most typical inorganic and organic contaminants. Aquatic pollution from metals and PAHs has been recorded for decades. Due to their ubiquitous use, they are still pervasive in the aquatic environment in recent years [1-3]. The detrimental effects of individual metals and PAHs on fish have been substantiated by a number of studies [4-6]. But still there are gaps in our knowledge on the combined toxicity of these pollutants [7], although co-contamination of metals and PAHs has been constantly found in the aquatic environment [8-10].

The modes of toxic action on non-target aquatic organisms between metals and PAHs are quite different. For instance, the metals are able to increase the reactive oxygen species (ROS) generation through redox cycling; the protein content and the catalytic activities of cytochrome P450 (CYP) enzymes can be reduced when ROS act as second messengers, leading to activation of kinases with phosphorylation of CYP proteins or when they interact with the iron of heme groups [11]. In contrast, most PAHs can be biologically oxidized by the CYP enzymes and in turn induce enzymatic activity. Hence, the interactive effects of metals and PAHs toward fish may be complex and, in fact, be far from those predicted in an additive way [7].

Being a biologically essential trace element, copper $(\mathrm{Cu})$ is widespread in aquatic systems [12]. But at elevated concentrations it can be toxic to fish associated with reproductive impairments, larval deformities, reduced growth, and behavioral changes, etc. [6]. For PAHs, previous studies focused mainly on the toxicity of high molecular weight (HMW) PAHs (5- and 6-fused aromatic ring, e.g., benzo[a]pyrene) on fish, because of their high mutagenicity and carcinogenicity. Though being less mutagenic, low molecular weight (LMW) PAHs such as fluorene (F1, 3-fused aromatic ring PAH) and fluoranthene (Fluo, 4-fused aromatic ring PAH) can represent much more ecological risk than HMW PAHs in the aquatic environment [13]. However, the effects of LMW PAHs on fish are sparsely described, especially in scenarios of coexposure with metals.

Here, to give a comprehensive account of the effects of binary mixtures of $\mathrm{Cu}$ plus $\mathrm{Fl}$ or Fluo on crucian carp (Carassius auratus), a wide range of biochemical biomarkers in fish tissues were applied in the present study. Phase I and II metabolism enzymes (the activities of 7-ethoxyresorufin O-deethylase (EROD) and glutathioneS-transferase (GST), respectively) and anti-oxidative enzyme (the activity of catalase (CAT)) were evaluated in fish liver. Moreover, as an advisable indicator of metal exposure, change in metallothionein (MT) content was determined in fish gills exposed to $\mathrm{Cu}^{2+}$ alone or in combination with PAHs. Through this study, we expect to provide a better understanding of the interactive effects between metals and PAHs on aquatic organisms.

\section{Experimental Procedures}

\section{Chemicals}

Fl, Fluo, $\beta$-Nicotinamide adenine dinucleotide 2'-phosphate-reduced tetrasodium salt (NADPH), 7-ethoxyresorufin, and haemoglobin were purchased from Sigma Chemical (St. Louis, MO, USA) and the stated purity was $>98 \%$. CuSO4 (analytical grade) was obtained from Shanghai Tingxin Chemistry Reagent Co., Ltd. (Shanghai, China). 1-chloro-2,4-dinitrobenzene (CDNB) and bovine serum albumin (BSA) were purchased from Shanghai Huixing Biochemistry Reagent Co., Ltd. (Shanghai, China), and the purity was $>98 \%$. All other chemicals were of analytical grade and were obtained from Shanghai Chemical Reagent Co., Ltd. (Shanghai, China).

\section{Animals and Exposure}

Immature fish were obtained from the Nanjing Institute of Fishery Sciences (Nanjing, China). The mean body weight and length of fish were $25.4 \pm 4.6 \mathrm{~g}$ and $11.8 \pm 1.6 \mathrm{~cm}$, respectively. Before batch tests, the fish were acclimatized in de-chlorinated municipal water $\left(\mathrm{CaCO}_{3}\right.$ $104.3 \pm 6.1 \mathrm{mg} \mathrm{L}^{-1}, \mathrm{pH} 7.1 \pm 0.3,16 \pm 2^{\circ} \mathrm{C}$ ) for two weeks. The fish were fed every day with uncontaminated commercial pellet food (Tetra Pond Sticks, Germany). Sewage and uneaten food were removed every other day by suction. The fish were not fed for $24 \mathrm{~h}$ prior to the experiments, and no food was provided during the test period.

Randomly assigned fish were divided into various exposure groups (four fish per treatment) under constant aeration. The fish loading rate ranged 0.7-1.0 $\mathrm{g} \mathrm{L}^{-1}$. $\mathrm{Cu}$ was added into the water in the solution form of $\mathrm{CuSO}_{4}$, while $\mathrm{Fl}$ and Fluo treatments were conducted via intraperitoneal injection after being dissolved in corn oil due to the extremely low solubility in water. Based on the earlier fish toxicological studies concerning the target chemicals [14-15], the nominal exposure concentrations were set as $0.01,0.02,0.04,0.08$, and $0.16 \mathrm{mg} \mathrm{L}^{-1}$ in the $\mathrm{Cu}$-alone treatments, and the Fl- and Fluo-alone exposure treatments were administrated at dosages of 2, 4, 6, 8, and $10 \mathrm{mg} \mathrm{kg}^{-1}$. In the binary exposure treatments (i.e., $\mathrm{Cu}+\mathrm{Fl}$ and $\mathrm{Cu}+$ Fluo), $10 \mathrm{mg} \mathrm{kg}^{-1} \mathrm{Fl}$ or Fluo in corn oil was injected into fish, which were kept in the $\mathrm{Cu}^{2+}$-contained water at concentrations ranging from 0.01 to $0.16 \mathrm{mg} \mathrm{L}^{-1}$. Two control treatments were employed: a blank control group and a solvent control group (corn oil). The test water renewal was performed every day. All the treatments were conducted in triplicate. After $96 \mathrm{~h}$ of exposure, the fish were sacrificed by cervical transection after being anaesthetized with buffered tricaine methanesulfonate (100 $\mathrm{mg} \mathrm{L}^{-1}$ ). The tissues (liver and gills) were removed 
immediately, washed in $0.15 \mathrm{M} \mathrm{KCl}$, weighed, and stored at $-80^{\circ} \mathrm{C}$.

\section{Enzyme Assays}

Liver samples were homogenized in nine volumes of cold buffer $(0.15 \mathrm{M} \mathrm{KCl}, 0.1 \mathrm{M}$ Tris- $\mathrm{HCl}, \mathrm{pH} 7.4)$ and then centrifuged for $25 \mathrm{~min}(10,000 \times \mathrm{g})$ at $4^{\circ} \mathrm{C}$. The supernatants were used as the tissue extract for enzymatic activity determination. Liver EROD activity was quantified at $572 \mathrm{~nm}$ using 96-well plates as described by [4]. The reaction mixture consisted of $140 \mu \mathrm{L}$ buffer $\left(0.1 \mathrm{~mol} \mathrm{~L}^{-1}\right.$ Tris, $\left.0.15 \mathrm{~mol} \mathrm{~L}^{-1} \mathrm{KCl}, \mathrm{pH} 8.0\right), 10 \mu \mathrm{L}$ of $2 \mu \mathrm{mol} \mathrm{L} \mathrm{L}^{-1} 7$-ethoxyresorufin, and $10 \mu \mathrm{L}$ microsomes. The reaction was initiated at $25^{\circ} \mathrm{C}$ by the addition of $40 \mu \mathrm{L}$ of $2.1 \mathrm{mg} \mathrm{mL}^{-1} \mathrm{NADPH}$. GST activity was determined at $340 \mathrm{~nm}$ by adapting to a microplate reader using $30 \mu \mathrm{L}$ of homogenate and $150 \mu \mathrm{L}$ of the reaction solution $(100 \mu \mathrm{L}$ of $0.1 \mathrm{mM}$ potassium phosphate, $10 \mu \mathrm{L}$ of $1.0 \mathrm{mM}$ 1-chloro-2,4-dinitrobenzene, $10 \mu \mathrm{L}$ of $1.0 \mathrm{mM}$

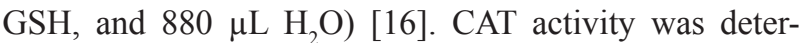
mined by the method of ammonium molybdate [17]. Initially, $200 \mu \mathrm{L}$ of the homogenate was incubated with $1 \mathrm{~mL}$ of substrate $(65 \mathrm{mM}$ hydrogen peroxide in $60 \mathrm{mM}$ potassium phosphate buffer, $\mathrm{pH} 7.4$ ) at $37^{\circ} \mathrm{C}$ for $60 \mathrm{~s}$. The enzymatic reaction was terminated by adding $1 \mathrm{~mL}$ of $32.4 \mathrm{mM}$ ammonium molybdate and yellow complex of molybdate and hydrogen peroxide was measured at $405 \mathrm{~nm}$.

Gill samples were homogenized in five volumes of cold phosphate buffer $0.1 \mathrm{M}(\mathrm{pH} 7.2$, triton $1 \%)$ on ice and centrifuged for $20 \mathrm{~min}(10,000 \times \mathrm{g})$ at $4^{\circ} \mathrm{C}$. The concentration of MT was determined by the $\mathrm{Cd}$ haemoglobin saturation method [18]. Five-hundred microliters of $200 \mathrm{mg} \mathrm{L}^{-1} \mathrm{CdCl}_{2}$ solution was added into $200 \mu \mathrm{L}$ of tissue homogenate and allowed to incubate at room temperature for 15 minutes. Then, $200 \mu \mathrm{L}$ of $2 \%$ bovine haemoglobin solution $(\mathrm{w} / \mathrm{v})$ was added to the sample, and the sample was mixed, heated, and centrifuged, after which the supernatant was collected. The $\mathrm{Cd}$ concentration in the supernatant was measured using flame atomic absorption equipment (TAS-986, Purkinje General Instrument Co. Ltd., Beijing, China), and the MT concentration was calculated from the $\mathrm{Cd}$ concentration measured in the supernatant.

Using the coomassie protein assay kit, protein concentrations were determined at $595 \mathrm{~nm}$ as previously described [19], with bovine serum albumin as standard.

\section{Data Analysis}

The results are expressed as the mean \pm standard deviation ( $\mathrm{SD}, n=3)$. The data from different treatments within each experiment were compared using two-way analysis of variance (ANOVA), and significant differences were identified by Dunnett's test. A $p$-value $<0.05$ was accepted to be statistically significant. Statistical analyses were conducted with SPSS statistical package (ver. 17.0, SPSS Company, Chicago, IL, USA).

\section{Results}

No mortality occurred during the 96-h exposure periods. Between the blank controls and the solvent controls, there were no significant differences in the responses of biomarkers in fish. Hence, liver EROD, GST, and CAT activities as well as MT content in gills in fish exposed to target compounds were compared with those in the blank controls. The activity of EROD in the liver tissues after $96 \mathrm{~h}$ of exposure to $\mathrm{Cu}^{2+}$ and PAHs are presented in Fig. 1. Compared to the control, both PAHs at the lower dosages ( 2 or $4 \mathrm{mg} \mathrm{kg}^{-1}$ ) did not change EROD activity obviously $(p>0.05)$; but at the higher dosages, Fl and Fluo significantly increased liver EROD activity to 1.5- and 1.3-fold, respectively (Fig. 1a). In contrast, liver EROD activity was remarkably inhibited by exposure to $\mathrm{Cu}^{2+}$ alone at the concentrations of $0.04,0.08$, and $0.16 \mathrm{mg} \mathrm{L}^{-1}$; the maximal inhibition rate obtained at the concentration of $0.16 \mathrm{mg} \mathrm{L}^{-1}$ was $30 \%$ (Fig. 1b). Compared to the isolated PAH exposures, the addition of $\mathrm{Cu}^{2+}$ decreased liver EROD activity in most cases. But both the co-treatments of $\mathrm{Cu}^{2+}$ and $\mathrm{Fl}$ or Fluo did not significantly alter liver EROD activity compared with that
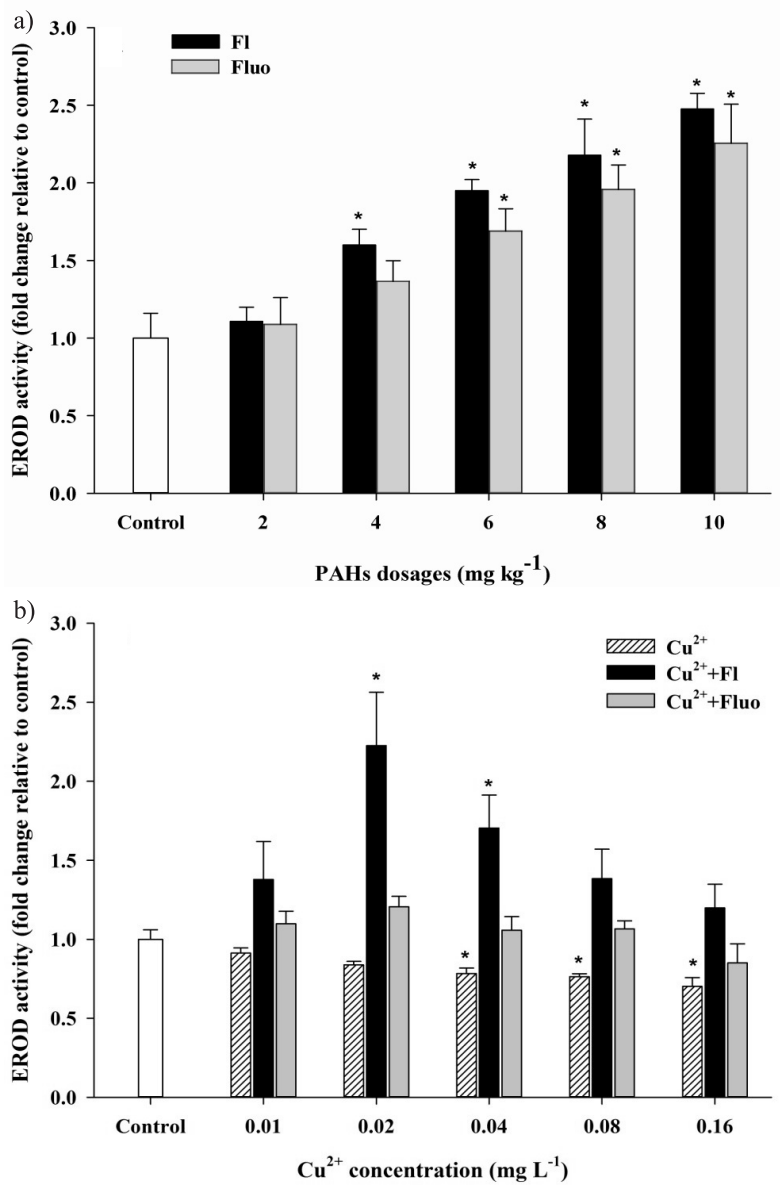

Fig. 1. Responses of liver EROD activity after 96-h exposure to: a) Fl, Fluo and b) $\mathrm{Cu}^{2+}$ alone and in combination with 10 $\mathrm{mg} \mathrm{kg}{ }^{-1} \mathrm{Fl}$ or Fluo. Error bars indicate $\pm \mathrm{SD}(n=3)$. Asterisks indicate values that are significantly different from control values $(p<0.05)$. 
in the control group, except at the $\mathrm{Cu}^{2+}$ concentrations of 0.02 and $0.04 \mathrm{mg} \mathrm{L}^{-1}$ in the $\mathrm{Cu}^{2+}$ and $\mathrm{Fl}$ treatments, where the liver EROD activity was acutely induced (1.2- and 0.7fold, respectively; Fig. 1b).

The activity of GST in the liver tissues after $96 \mathrm{~h}$ of exposure to $\mathrm{Cu}^{2+}$ and PAHs are presented in Fig. 2 . Across all the test dosages, Fl and Fluo significantly increased GST activity (Fig. 2a). Both the Fl and Fluo exposures resulted in the greatest GST increase (2.0and 1.5-fold, respectively) at the highest dosages of $10 \mathrm{mg} \mathrm{kg}{ }^{-1}$. As shown in Fig. 2b), at the nominal concentrations of 0.01 and $0.02 \mathrm{mg} \mathrm{L}^{-1}$, GST activity was markedly increased (1.1- and 1.6-fold, respectively) by the $\mathrm{Cu}^{2+}$-alone treatment; but at higher concentrations $\left(0.04,0.08\right.$, and $\left.0.16 \mathrm{mg} \mathrm{L}^{-1}\right)$, the GST activity did not show obvious differences from the control. Compared to the control, the liver GST activity was not significantly changed by the co-treatment of $\mathrm{Cu}^{2+}$ plus $\mathrm{Fl}(p>0.05)$. However, the binary exposure of $\mathrm{Cu}^{2+}$ at concentrations of $0.01,0.02$, and $0.04 \mathrm{mg} \mathrm{L}^{-1}$ plus Fluo did increase the liver GST activity with the maximal induction of 1.6-fold.

The activity of CAT in the liver tissues after $96 \mathrm{~h}$ of exposure to $\mathrm{Cu}^{2+}$ and PAHs are presented in Fig. 3. Fland Fluo-alone exposures decreased liver CAT activity at
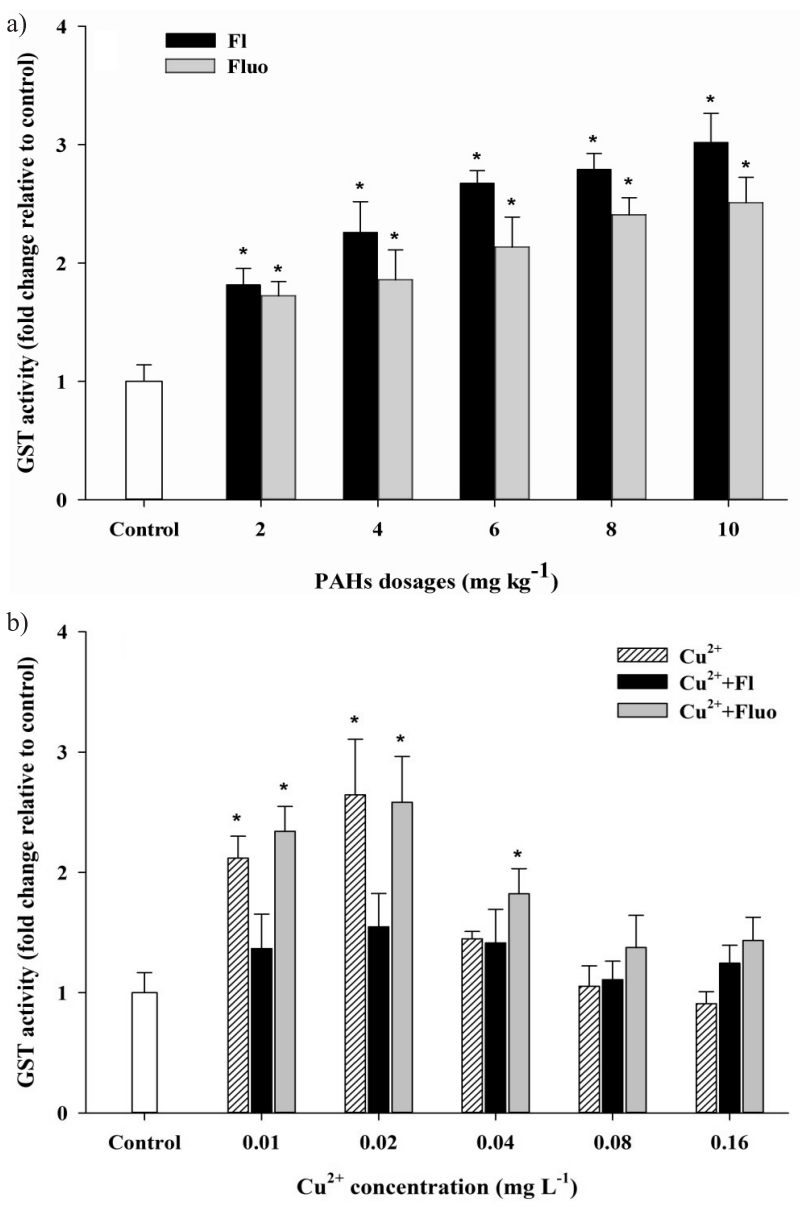

Fig. 2. Responses of liver GST activity after 96-h exposure to a) $\mathrm{Fl}$, Fluo and b) $\mathrm{Cu}^{2+}$ alone and in combination with $10 \mathrm{mg} \mathrm{kg}^{-1} \mathrm{Fl}$ or Fluo. Error bars indicate $\pm \mathrm{SD}(n=3)$. Asterisks indicate values that are significantly different from control values $(p<0.05)$. all the dosages (Fig. 3a). The two highest dosages ( 8 and $10 \mathrm{mg} \mathrm{kg}^{-1}$ ) of PAHs significantly inhibited CAT activity with the maximal inhibition rate of $46 \%$ by $\mathrm{Fl}$ exposure and $62 \%$ by Fluo exposure. As shown in Fig. 3b), when compared to the control, no obvious difference in CAT activity was observed in fish liver exposed to $\mathrm{Cu}^{2+}$ alone $(p>0.05)$. In fish liver exposed to the mixtures of $\mathrm{Cu}^{2+}$ and Fl, CAT activity was markedly inhibited (inhibition rate of $36 \%$ ) only at the $\mathrm{Cu}^{2+}$ concentration of $0.16 \mathrm{mg} \mathrm{L}^{-1}$, while the combination of $\mathrm{Cu}^{2+}$ and Fluo obviously suppressed CAT activity in most cases with the most significant inhibition rate of $50 \%$ (Fig. $3 b$ ).

The MT content in the gills after $96 \mathrm{~h}$ of exposure to $\mathrm{Cu}^{2+}$ and PAHs are presented in Fig. 4. As shown in Fig. 4a), MT content in fish gills was not obviously affected by the PAH-alone treatments at all the test dosages $(p>0.05)$. But a concentration-dependent increase of MT content was observed in $\mathrm{Cu}^{2+}$-alone treatment, reaching the maximal fold change (1.2-fold) at the highest exposure concentration (Fig. 4b). Similarly, MT content in the gills was distinctly increased by the combinations of $\mathrm{Cu}^{2+}+\mathrm{Fl}$ and $\mathrm{Cu}^{2+}+$ Fluo (with the greatest increases of 0.9 - and 0.8 fold, respectively) in most cases, although slightly lower than that in the $\mathrm{Cu}^{2+}$-only counterparts (Fig. $4 \mathrm{~b}$ ).
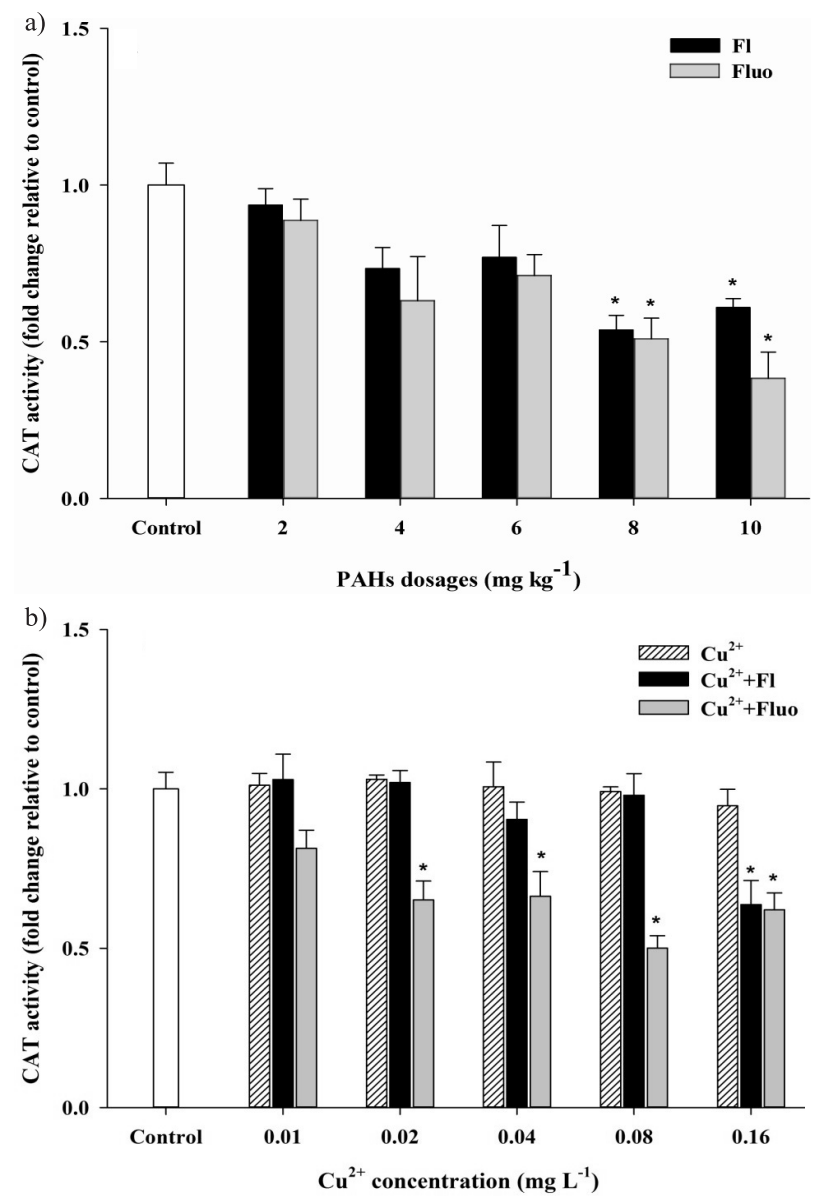

Fig. 3. Responses of liver CAT activity after 96-h exposure to a) Fl, Fluo and b) $\mathrm{Cu}^{2+}$ alone and in combination with $10 \mathrm{mg} \mathrm{kg}^{-1} \mathrm{Fl}$ or Fluo. Error bars indicate $\pm \mathrm{SD}(n=3)$. Asterisks indicate values that are significantly different from control values $(p<0.05)$. 

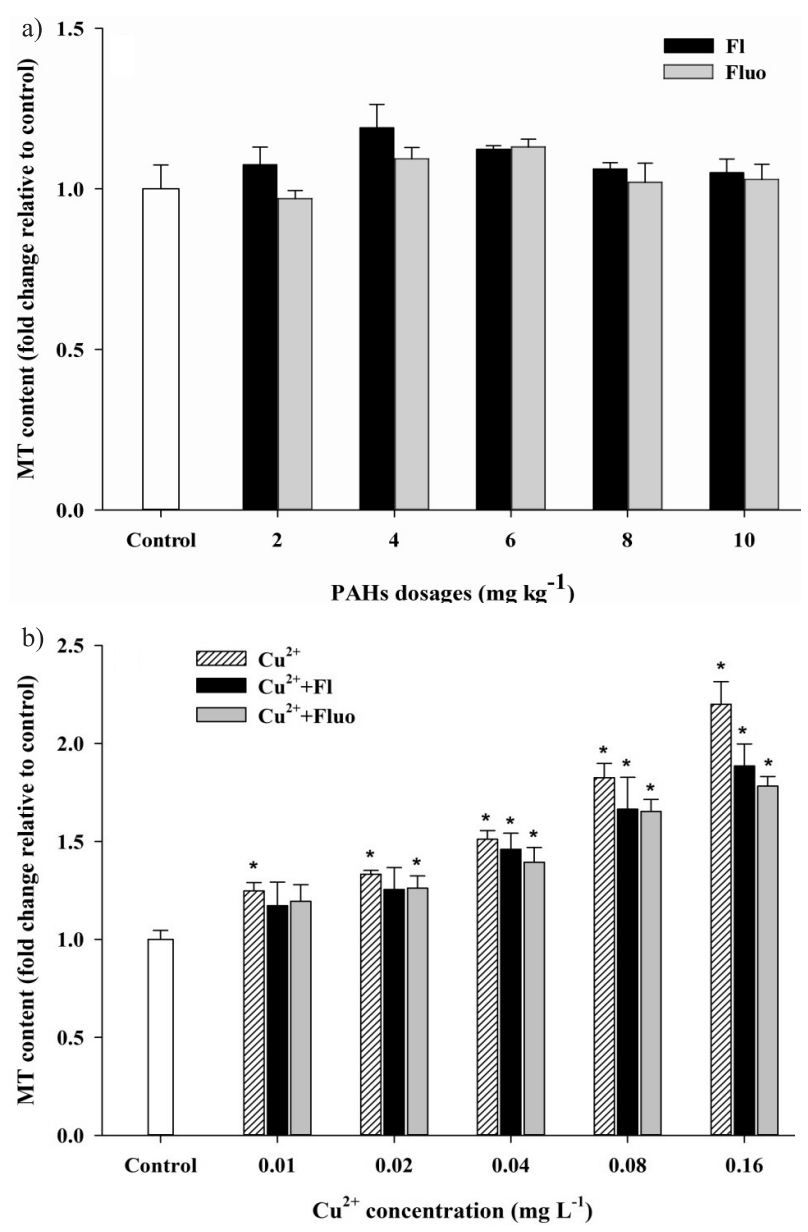

Fig. 4. Responses of gill MT content after 96-h exposure to a) Fl, Fluo and b) $\mathrm{Cu}^{2+}$ alone and in combination with $10 \mathrm{mg} \mathrm{kg}^{-1} \mathrm{Fl}$ or Fluo. Error bars indicate $\pm \mathrm{SD}(n=3)$. Asterisks indicate values that are significantly different from control values $(p<0.05)$.

\section{Discussion of Results}

In general, xenobiotics are metabolized in fish through a two-step process involving a biotransformation step with CYP enzymes (phase I) accompanied by a conjugation step with GST (phase II). Associated with CYP1A, EROD can catalyze phase I metabolism of many chemicals. Hence, numerous fish studies used this enzyme as a biomarker for potential phase I metabolism. In the present study, liver EROD activity was increased by the isolated Fl and Fluo exposures at the higher dosages, which was in agreement with a previous finding in C. auratus [4]. Conversely, linking the inability to bind to Ah-receptor (AhR) and initiate transcription $[15,20]$, unapparent change or even inhibition of EROD activity by Fl and Fluo exposures has been reported in in vivo studies with other fish species, including zebrafish (Danio rerio) [21], gilthead seabream (Sparus aurata) [22], and mummichog (Fundulus heteroclitus) [15]. These results suggest that, unlike most HMW PAHs, the biochemical response to LMW PAHs may not be uniform among different fish species. Due to the great diversity found in some 28,000 fish species [23], there could be large intrinsic variations in the affinity of the
AhR of different fish species to small molecular-size PAH compounds [22, 24]. Unlike Fl and Fluo, single exposure to $\mathrm{Cu}^{2+}$ inhibited the liver EROD activity in $C$. auratus in this study, as also found in other fish species exposed to $\mathrm{Cu}^{2+}$ [25-27]. When co-treated with $\mathrm{Fl}$ and Fluo, the addition of $\mathrm{Cu}^{2+}$ also led to a decrease in EROD induction, compared respectively to that in the fish treated only with $10 \mathrm{mg} \mathrm{kg}^{-1} \mathrm{Fl}$ and Fluo. Similarly, reduction by zinc(II) in benzo $(k)$ fluoranthene-increased EROD activity has been observed in the C. auratus hepatocytes [28]. Inhibition in liver EROD activity may be due to the divalent metal ions that can bind to the sulfhydryl group, leading to a protein conformational change and consequently disrupting the normal function of the enzyme [27, 29-30]. Thus, in field sites with multi-pollution of environmental stressors, detection of PAH pollution by EROD activity might be masked by the simultaneous presence of such metals [31].

After biotransformation, metabolites will experience conjugation process and eventually convert into more water-soluble forms to be excreted from the body, which is usually related to catalysis by GST. Moreover, by metabolizing lipid hydroperoxides in response to ROS production, GST plays a critical role in the antioxidant defense system [32]. In this study, the marked increase of GST activity was observed in the fish liver exposed to Fl and Fluo alone. The increased GST activity by Fl or Fluo was also recorded in the same species [4, 33] and different species, such as crab (Carcinus maenas) [34]. These results suggest the involvement of GST in the detoxification of these two PAHs and the occurrence of oxidative stress response in aquatic organisms to F1 and Fluo exposure. GST activity in liver was significantly increased at the lower concentrations of $\mathrm{Cu}^{2+}$ $\left(\leq 0.02 \mathrm{mg} \mathrm{L}^{-1}\right)$ but began to decrease at the higher concentrations. Considering that the EROD activity was inhibited by $\mathrm{Cu}^{2+}$ in the present study, the increase in GST activity in the fish liver exposed to lower concentrations of $\mathrm{Cu}^{2+}$ could be related to enhanced ROS production, in accordance with the hypothesis that $\mathrm{Cu}^{2+}$ would directly cause oxidative stress via Fenton reaction [25], while the unchanged GST activity at the higher $\mathrm{Cu}^{2+}$ concentrations might be due to the fact that excess $\mathrm{Cu}^{2+}$ causes rapid glutathione (GSH) oxidation, and also reduces the GSH/oxidized glutathione (GSSG) ratio in hepatocytes, followed by GST depletion [35-36]. In regards to binary co-exposure groups, the fish exposed to $\mathrm{Cu}^{2+}$ plus $\mathrm{Fl}$ or Fluo did not show any obvious changes in liver GST activity compared to the control in most cases, suggesting that the addition of $\mathrm{Cu}^{2+}$ has reduced the induction of GST activity caused by $\mathrm{Fl}$ or Fluo exposure. Lack of effects on GST activity may also be attributed to the variation of GSH/GSSG ratio, as co-exposure of $\mathrm{Cu}^{2+}$ and PAHs would lead to stronger GSH oxidation. Collectively, the interaction between metals and PAHs could elicit inhibiting effects on EROD and GST activities in fish liver compared to those in the isolated treatments. The result indicates that coexistence of metals and PAHs may hamper the activation of fish metabolic enzymes, and eventually result in the bioaccumulation risks of these contaminants. 
In addition to GST, CAT is also an extensively expressed antioxidant enzyme in fish. Located in the peroxisomes, CAT is able to catalyze the decomposition of hydrogen peroxide to oxygen and water [37]. The available data in fish studies, which concerns the response of CAT activity on LMW PAHs exposure, is not consistent when some demonstrate stimulation in CAT activity [3839] while others report no change or even significant inhibition in this enzyme activity [22]. In our study, fish liver CAT activity obviously decreased by isolated exposure to $\mathrm{Fl}$ and Fluo (8 and $10 \mathrm{mg} \mathrm{kg}^{-1}$ ), suggesting that these two PAHs at high doses may inhibit CAT activity and thus suppress the scavenging capacity of fish to ROS. Inhibited CAT activity together with elevated GST activity indicate a perturbation of antioxidant enzyme systems and potential oxidative damage in the fish hepatocytes caused by Fl and Fluo. The lack of response of CAT activity on $\mathrm{Cu}^{2+}$ exposure was observed in the liver of $C$. auratus in this study, and other fish species including tilapia (Oreochromis niloticus) [40], catfish (Rhamdia quelen) [25], and neotropical fish (Prochilodus lineatus) [41], indicating that CAT activity in fish may not be a sensitive biomarker for $\mathrm{Cu}$ pollution. For the binary exposure of $\mathrm{Cu}^{2+}$ and $\mathrm{Fl}$, the liver CAT activity was still unchanged in most cases. However, the activity of this enzyme was significantly inhibited by exposure to the mixture of $\mathrm{Cu}^{2+}$ and Fluo in this study. This result demonstrated that the antioxidant system of $C$. auratus may fail to scavenge overproduced ROS by co-exposure to $\mathrm{Cu}^{2+}$ and Fluo.

Owing to the wide surface area in contact with water, gills are an important uptake route of organisms for waterborne pollutants [42]. Among metal ligands, induced MTs are involved in non-enzymatic homeostasis and a detoxification mechanism of fish against metal exposure. In previous studies, the induction of MT content in fish gills exposed to metals has been documented in tilapia (Oreochromis mossambicus) [43-44], common carp (Cyprinus carpio) [45-46], and catfish (Clarias gariepinus) [47]. Our study also demonstrated that waterborne exposure to $\mathrm{Cu}^{2+}$ could increase MT contents in gills of $C$. auratus in a concentration-dependent manner, confirming that MT synthesis level in $C$. auratus gills is a sensitive biomarker for aquatic pollution of metals. Although Fl- and Fluo-alone exposures did not obviously change the MT content in gills, joint exposures of $\mathrm{Cu}^{2+}$ and $\mathrm{Fl}$ or Fluo still enabled the increase of MT levels in most cases in the present study. But it should be noted that co-administrations with Fl and Fluo slightly decreased the MT synthesis when compared to exposure to $\mathrm{Cu}^{2+}$ alone. The down-regulation of metal-induced MT levels in fish by PAHs has been found in some earlier studies, and this observation may be due to competition for cysteine residues by GSH synthesis [28, 48]. Moreover, this indicates that co-exposure with PAHs may suppress elimination of $\mathrm{Cu}$ ions, and thus enhance accumulation and toxicity of $\mathrm{Cu}^{2+}$ in fish.

\section{Conclusions}

This study shows various biochemical effects in crucian carp (C. auratus) exposed to the metal $\mathrm{Cu}$ ion, the $\mathrm{PAHs} \mathrm{Fl}$ and Fluo, and their binary mixtures. After $96 \mathrm{~h}$ of exposure, liver EROD and GST activities seemed not to be obviously affected by the co-exposure of $\mathrm{Cu}^{2+}$ combined with Fl or Fluo. This suggests that these two enzymes in C. auratus may be of limited use in the ecological risk assessment of multi-pollution by metals and PAHs. However, liver CAT activity was significantly inhibited by $\mathrm{Cu}^{2+}$ and Fluo exposure, and MT content in gills was highly active to both the co-treatments of $\mathrm{Cu}^{2+}$ and Fl or Fluo. These results indicate that the joint exposure of metals and PAHs could trigger more severe accumulation risks and oxidative stress in $C$. auratus. Despite these results, further study is required to understand deeply and to develop more appropriate biomarkers of the interaction with metals and PAHs in fish.

\section{Acknowledgements}

This study was supported by the National Science Funds for Creative Research Groups of China (grant No. 51421006) and the Support Program for the Yarlung Zangbo Scholars of Agricultural and Animal Husbandry College of Tibet (grant No. 2015XYA01).

\section{References}

1. KONG M., HANG X., WANG L., YIN H., ZHANG Y. Accumulation and risk assessment of heavy metals in sediments and zoobenthos (Bellamya aeruginosa and Corbicula fluminea) from Lake Taihu. Water Science and Technology, 73(1), 203, 2016.

2. SU H., WU F., GUO J., HU Y., FENG C., CHEN C., GIESY J.P. Distribution characteristics and risk assessments of PAHs in fish from Lake Taihu, China. Human and Ecological Risk Assessment, 21, 1753, 2015.

3. VARNOSFADERANY M.N., BAKHTIARI A.R., GU Z., CHU G. Distribution and characteristic of PAHs in sediments from the southwest Caspian Sea, Guilan Province, Iran. Water Science and Technology, 71, 1587, 2015.

4. LU G.H., WANG C., ZHU Z. The dose-response relationships for EROD and GST induced by polyaromatic hydrocarbons in Carassius auratus. Bulletin of Environmental Contamination and Toxicology, 82, 194, 2009.

5. REYNAUD S., DESCHAUX P. The effects of polycyclic aromatic hydrocarbons on the immune system of fish: a review. Aquatic Toxicology, 77, 229, 2006.

6. SFAKIANAKIS D.G., RENIERI E., KENTOURI M., TSATSAKIS A.M. Effect of heavy metals on fish larvae deformities: a review. Environmental Research, 137, 246, 2015.

7. GAUTHIER P.T., NORWOOD W.P., PREPAS E.E., PYLE G.G. Metal-PAH mixtures in the aquatic environment: 
A review of co-toxic mechanisms leading to more-thanadditive outcomes. Aquatic Toxicology, 154, 253, 2014.

8. STORELLI M.M., BARONE G., PERRONE V.G., STORELLI A. Risk characterization for polycyclic aromatic hydrocarbons and toxic metals associated with fish consumption. Journal of Food Composition and Analysis, 31, 115, 2013.

9. TZORAKI O., KARAOUZAS I., PATROLECCO L., SKOULIKIDIS N., NIKOLAIDIS N.P. Polycyclic aromatic hydrocarbons (PAHs) and heavy metal occurrence in bed sediments of a temporary river. Water, Air, \& Soil Pollution, 226, 1, 2015.

10. WANG C., LU G., WANG P., WU H., QI P., LIANG Y. Assessment of environmental pollution of Taihu Lake by combining active biomonitoring and integrated biomarker response. Environmental Science \& Technology, 45, 3746, 2011.

11. BENEDETTI M., MARTUCCIO G., FATTORINI D., CANAPA A., BARUCCA M., NIGRO M., REGOLI F. Oxidative and modulatory effects of trace metals on metabolism of polycyclic aromatic hydrocarbons in the Antarctic fish Trematomus bernacchii. Aquatic Toxicology, 85, 167, 2007.

12. TRAN D., FOURNIER E., DURRIEU G., MASSABUAU J.C. Copper detection in the Asiatic clam Corbicula fluminea: optimum valve closure response. Aquatic Toxicology, 65, 317, 2003.

13. YAN J., LIU J., SHI X., YOU X., CAO Z. Polycyclic aromatic hydrocarbons (PAHs) in water from three estuaries of China: Distribution, seasonal variations and ecological risk assessment. Marine Pollution Bulletin, 109, 471-479, 2016.

14. SÁEZ M. I., GARCÍA-MESA S., CASAS J.J., GUILGUERRERO J.L., VENEGAS-VENEGAS C.E., MORALES A.E., SUÁREZ M.D. Effect of sublethal concentrations of waterborne copper on lipid peroxidation and enzymatic antioxidant response in Gambusia holbrooki. Environmental Toxicology and Pharmacology, 36, 125, 2013.

15. WILLETT K.L., WASSENBERG D., LIENESCH L., REICHERT W., DI GIULIO R.T. In vivo and in vitro inhibition of CYP1A-dependent activity in Fundulus heteroclitus by the polynuclear aromatic hydrocarbon fluoranthene. Toxicology and Applied Pharmacology, 177, 264, 2001.

16. FRASCO M.F., GUILHERMINO L. Effects of dimethoate and beta-naphthoflavone on selected biomarkers of Poecilia reticulata. Fish Physiology and Biochemistry, 26, 149, 2002.

17. GOTH L. A simple method for determination of serum catalase activity and revision of reference range. Clinica Chimica Acta, 196, 143, 1991.

18. ONOSAKA S., CHERIAN M.G. Comparison of metallothionein determination by polarographic and cadmium-saturation methods. Toxicology and Applied Pharmacology, 63, 270, 1982.

19. BRADFORD M.M. A rapid and sensitive method for the quantitation of microgram quantities of protein utilizing the principle of protein-dye binding. Analytical Biochemistry, 72, 248, 1976.

20. WESSEL N., MÉNARD D., PICHAVANT-RAFINI K., OLLIVIER H., LE GOFF J., BURGEOT T., AKCHA F. Genotoxic and enzymatic effects of fluoranthene in microsomes and freshly isolated hepatocytes from sole (Solea solea). Aquatic Toxicology, 108, 33, 2012.

21. MATSON C.W., TIMME-LARAGY A.R., DI GIULIO R.T. Fluoranthene, but not benzo[a]pyrene, interacts with hypoxia resulting in pericardial effusion and lordosis in developing zebrafish. Chemosphere, 74, 149, 2008.

22. KOPECKA-PILARCZYK J., CORREIA A.D. Biochemical response in gilthead seabream (Sparus aurata) to in vivo exposure to pyrene and fluorene. Journal of Experimental Marine Biology and Ecology, 372, 49, 2009.

23. OWEN S.F., GILTROW E., HUGGETT D.B., HUTCHINSON T.H., SAYE J., WINTER M.J., SUMPTER J.P. Comparative physiology, pharmacology and toxicology of $\beta$-blockers: mammals versus fish. Aquatic Toxicology, 82, 145, 2007.

24. SHAILAJA M.S., D'SILVA C. Evaluation of impact of PAH on a tropical fish, Oreochromis mossambicus using multiple biomarkers. Chemosphere, 53, 835, 2003.

25. MELA M., GUILOSKI I.C., DORIA H.B., RABITTO I.S., DA SILVA C.A., MARASCHI A.C., PRODOCIMO V., FREIRE C.A., RANDI M.A.F., OLIVEIRA RIBEIRO C.A. SILVA DE ASSIS H.C. Risks of waterborne copper exposure to a cultivated freshwater Neotropical catfish (Rhamdia quelen). Ecotoxicology and Environmental Safety, 88, 108, 2013.

26. SANCHEZ W., PALLUEL O., MEUNIER L., COQUERY M., PORCHER J.M., AIT-AISSA S. Copper-induced oxidative stress in three-spined stickleback: relationship with hepatic metal levels. Environmental Toxicology and Pharmacology, 19, 177, 2005.

27. VIEIRA L.R., GRAVATO C., SOARES A.M.V.M., MORGADO F., GUILHERMINO L. Acute effects of copper and mercury on the estuarine fish Pomatoschistus microps: linking biomarkers to behaviour. Chemosphere, 76, 1416, 2009.

28. DING J., LU G., LIANG Y. Evaluation of the interactive effects of lead, zinc and benzo $(k)$ fluoranthene on crucian carp, Carassius carassius, using a multiple biomarker approach. Bulletin of Environmental Contamination and Toxicology, 92, 534, 2014.

29. BOZCAARMUTLU A., ARINÇ E. Inhibitory effects of divalent metal ions on liver microsomal 7-ethoxyresorufin $O$-deethylase (EROD) activity of leaping mullet. Marine Environmental Research, 58, 521, 2004.

30. GHOSH M.C., GHOSH R., RAY A.K. Impact of copper on biomonitoring enzyme ethoxyresorufin-o-deethylase in cultured catfish hepatocytes. Environmental Research, 86, 167, 2001.

31. TRAVEN L., MIĆOVIĆ V., LUŠIĆ D.V., SMITAL T. The responses ofthehepatosomaticindex(HSI), 7-ethoxyresorufinO-deethylase (EROD) activity and glutathione-S-transferase (GST) activity in sea bass (Dicentrarchus labrax, Linnaeus 1758) caged at a polluted site: implications for their use in environmental risk assessment. Environmental Monitoring and Assessment, 185, 9009, 2013.

32. MOURENTE G., DIAZ-SALVAGO E., BELL J.G., TOCHER D.R. Increased activities of hepatic antioxidant defence enzymes in juvenile gilthead sea bream (Sparus aurata L.) fed dietary oxidised oil: attenuation by dietary vitamin E. Aquaculture, 214, 343, 2002.

33. LU G.H., CHEN W., LI Y., ZHU Z. Effects of PAHs on biotransformation enzymatic activities in fish. Chemical Research in Chinese Universities, 27, 413, 2011.

34. RODRIGUES A.P., LEHTONEN K.K., GUILHERMINO L., GUIMARÃES L. Exposure of Carcinus maenas to waterborne fluoranthene: accumulation and multibiomarker responses. Science of the Total Environment, 443, 454, 2013.

35. ATLI G., CANLI M. Response of antioxidant system of freshwater fish Oreochromis niloticus to acute and chronic 
metal $(\mathrm{Cd}, \mathrm{Cu}, \mathrm{Cr}, \mathrm{Zn}, \mathrm{Fe})$ exposures. Ecotoxicology and Environmental Safety, 73, 1884, 2010.

36. ATLI G., GROSELL M. Characterization and response of antioxidant systems in the tissues of the freshwater pond snail (Lymnaea stagnalis) during acute copper exposure. Aquatic Toxicology, 176, 38, 2016.

37. SALMON A.B., RICHARDSON A., PÉREZ V.I. Update on the oxidative stress theory of aging: does oxidative stress play a role in aging or healthy aging? Free Radical Biology and Medicine, 48, 642-655, 2010.

38. BUETA., BANAS D., VOLLAIRE Y., COULETE., ROCHE H. Biomarker responses in European eel (Anguilla anguilla) exposed to persistent organic pollutants. A field study in the Vaccarès lagoon (Camargue, France). Chemosphere, 65, 1846, 2006.

39. KOPECKA-PILARCZYK J., CORREIA A.D. Biochemical response in gilthead seabream (Sparus aurata) to in vivo exposure to a mix of selected PAHs. Ecotoxicology and Environmental Safety, 72, 1296, 2009.

40. ATLI G., CANLI M. Enzymatic responses to metal exposures in a freshwater fish Oreochromis niloticus. Comparative Biochemistry and Physiology, 145C, 282, 2007.

41. SIMONATO J.D., MELA M., DORIA H.B., GUILOSKI I.C., RANDI M.A., CARVALHO P.S., MELETTI P.C., SILVA DE ASSIS H.C., BIANCHINI A., MARTINEZ C.B.R. Biomarkers of waterborne copper exposure in the Neotropical fish Prochilodus lineatus. Aquatic Toxicology, 170, 31, 2016.

42. PIAZZA R.S., TREVISAN R., FLORES-NUNES F., TOLEDO-SILVA G., WENDT N., MATTOS J.J., LIMA D., TANIGUCHI S., SASAKI S.T., MELLO Á.C.P., ZACCHI F.L., SERRANO M.A.S., GOMES C.H.A.M., BÍCEGO
M.C., DE ALMEIDA E.A., BAINY A.C.D. Exposure to phenanthrene and depuration: Changes on gene transcription, enzymatic activity and lipid peroxidation in gill of scallops Nodipecten nodosus. Aquatic Toxicology, 177, 146-155, 2016.

43. DANG Z., LOCK R.A., FLIK G., BONGA, S.E.W. Metallothionein response in gills of Oreochromis mossambicus exposed to copper in fresh water. American Journal of Physiology-Regulatory, 277, R320, 1999.

44. NAJI A., ISMAIL A., KAMRANI E., SOHRABI T. Correlation of MT levels in livers and gills with heavy metals in wild tilapia (Oreochromis mossambicus) from the Klang River, Malaysia. Bulletin of Environmental Contamination and Toxicology, 92, 674, 2014.

45. DE SMET H., DE WACHTER B., LOBINSKI R., BLUST R. Dynamics of $(\mathrm{Cd}, \mathrm{Zn})$-metallothioneins in gills, liver and kidney of common carp Cyprinus carpio during cadmium exposure. Aquatic Toxicology, 52, 269, 2001.

46. SEVCIKOVA M., MODRA H., BLAHOVA J., DOBSIKOVA R., PLHALOVA L., ZITKA O., HYNEK D., KIZEK R., SKORIC M., SVOBODOVA Z. Biochemical, haematological and oxidative stress responses of common carp (Cyprinus carpio L.) after sub-chronic exposure to copper. Veterinarni Medicina, 61, 35, 2016.

47. ROSE S., VINCENT S., MEENA B., SURESH A., MANI R. Metallothionein induction in fresh water catfish Clarias gariepinus on exposure to cadmium. International Journal of Pharmacy and Pharmaceutical Sciences, 6, 377, 2014.

48. VAN DEN HURK P., FAISAL M., ROBERTS JR M.H. Interactive effects of cadmium and benzo[a]pyrene on metallothionein induction in mummichog (Fundulus heteroclitus). Marine Environmental Research, 50, 83, 2000. 